\title{
NEW KNOWLEDGE ON THE MONTE CONCA GYPSUM KARST SYSTEM (CENTRAL-WESTERN SICILY, ITALY)
}

\author{
NOVA SPOZNANJA V KRAŠKEM SISTEMU MONTE CONCA \\ (SICILIJA, ITALIJA)
}

\author{
Giuliana MADONIA $^{1} \&$ Marco VATTANO $^{1}$
}

\begin{abstract}
UDC 551.435.8(450.82)

Giuliana Madonia \& Marco Vattano: New knowledge on the Monte Conca gypsum karst system (central-western Sicily, Italy)

The Monte Conca karst system is located in Central-Western Sicily, where Messinian evaporites are widespread. Here, the evaporites lie on lower Messinian-middle Serravallian clayeymarly-sandy deposits and are overlain locally by Pliocene marly limestones. These successions are affected by E-W, and to a lesser degree N-S and NW-SE, high-angle faults that have also produced lateral contacts between the gypsum units and the clayey-marly deposits. The cave passages reach altogether about $2.4 \mathrm{~km}$ in length and $130 \mathrm{~m}$ in depth, and the system consists of a sink cave, a resurgence and a relict resurgence. At large scale it is characterized by superimposed levels of subhorizontal galleries connected by vertical shafts, which are developed in adjustment to the contemporary geomorphological setting. Until 2003, the sink cave was known to have been formed by a stream-sink, an upper horizontal gallery, a sequence of four shafts and a lower gallery. New explorations have discovered $1.5 \mathrm{~km}$ of relict passages that are correlatable with the inactive resurgence level and that occur at intermediate elevations between the two stories of galleries. Sinks of these relict branches are located headward of the actual sink point, but they have been sealed and covered by thick debris and alluvial deposits from the surface slopes. The resurgence consists of two superimposed galleries, the upper one inactive and the lower one active in equilibrium with the current local base level. The relict resurgence is located about $40 \mathrm{~m}$ above the resurgence and is characterized by a sub-horizontal gallery partially filled by copious alluvial deposits. Analysis of the gallery patterns and of the cave landforms suggests that the karst system is a multi-layer system formed under unconfined conditions. Additionally, analysis suggests that its evolution is due to a succession of stillstand and lowering phases of the karst base level, according to a regional uplifting trend, and to sur-
\end{abstract}

\section{Izvleček \\ UDK 551.435.8(450.82) \\ Giuliana Madonia \& Marco Vattano: Nova spoznanja $v$ kraškem sistemu Monte Conca (Sicilija, Italija)}

Kraški sistem Monte Conca je v osrednjem delu zahodne Sicilije, kjer so precej razširjeni mesinski evaporiti. Ti ležijo na spodnje mesinskih in srednje seravalskih glineno-lapornopeščenih sedimentih, lokalno pa jih prekrivajo pliocenski lapornati apnenci. Celotno zaporedje je prizadeto s strmimi prelomi, predvsem $\mathrm{v}$ smeri E-W in manj $\mathrm{v}$ smeri N-S oz. NW-SE. Prelomi so tudi vzrok za lateralni stik med sadro in glineno-lapornimi sedimenti. Celotna dolžina jamskih rovov je $2,4 \mathrm{~km}$, globina doseže $130 \mathrm{~m}$. Sistem sestavljajo ponorna jama, izvirna jama in reliktni izvir. Sestavlja ga več nivojev, ki so povezani $\mathrm{z}$ vertikalnimi brezni in predstavljajo odziv na spremembo lokalne topografije. Pred letom 2003 je bila poznana ponorna jama, zgornja horizontalna galerija, niz štirih brezen in spodnja galerija. Nove raziskave so prinesle $1,5 \mathrm{~km}$ novo odkritih rovov med zgornjim in spodnjim nivojem, ki se navezujejo na višji neaktiven izvir. Ponori teh fosilnih rovov so danes zapolnjeni $\mathrm{z}$ aluvijalnimi sedimenti in se nahajajo $\mathrm{v}$ smeri proti izvirom glede na aktivne ponore. Izvirno jamo sestavljata dve galeriji, višje ležeča neaktivna in aktivna galerija, ki je v nivoju trenutne erozijske baze. Reliktni izvir je 40 m nad sedanjim izvirom in se nadaljuje $\mathrm{z}$ nagnjeno galerijo, ki je delno napolnjena $\mathrm{z}$ aluvijem. Iz geometrije in porazdelitve jamskih prostorov sklepamo, da je jama nastala v odprtem vodonosniku. Razvoj je potekal skozi niz stabilnih obdobij in vmesnega poglabljanja erozijske baze, ki ustreza lokalnemu tektonskemu dvigovanju območja. Končna oblika sistema je tudi posledica pobočnih procesov.

Ključne besede: sadra, kraški sistem, speleogeneza, Monte Conca, Sicilija.

\footnotetext{
${ }^{1}$ Università degli Studi di Palermo, Dipartimento di Geologia e Geodesia, Via Archirafi 20/22, 90123 Palermo, Italy, e-mail:vattano@unipa.it
}

Received/Prejeto: 9.9.2010 
face slope processes, which have complicated the structure of the karst system.

Keywords: gypsum, karst system, speleogenesis, Monte Conca, Sicily.

\section{INTRODUCTION}

In Sicily, gypsum karst is well developed according to the large extension of Messinian evaporites, which outcrop over $1,000 \mathrm{~km}^{2}$, mainly in the south, central and in western part of the island. The evaporites, referred to as the Serie Gessoso-Solfifera (Baldacci 1886), generally overlie older impervious units and are covered by insoluble Pliocene and Pleistocene rocks.

Gypsum karst mainly develops under exposed conditions where the insoluble covers have been completely removed by erosion processes (Klimchouk \& Ford 2000); karst shows different kinds of landscapes according to the different geological and environmental settings (Macaluso et al. 2001; Sauro 2003), with the development of surface and underground forms. The surface karst landforms show a large variety of typologies, ranging in size from a few microns to some kilometers (Macaluso \& Sauro 1996a, b, 1998; Sauro 1996; Ferrarese et al. 2002; Agnesi et al. 2003; Macaluso et al. 2003).

The underground landforms are represented by more than 200 solution caves and tectonic caves.

Solution caves are generally developed from a swallow hole in the bottom of dolines or at the end of blind valleys; in some cases, cave entrances are opened in correspondence with karst springs.

The caves develop entirely in the gypsum units, and their setting reflects the features of a classic gypsum karst system under unconfined conditions. The caves are com- posed of a main drainage tube in equilibrium with the elevation of springs, with not very developed secondary tributaries, frequently filled by alluvial and/or breakdown deposits (Forti \& Sauro 1996; Forti \& Rossi 2003).

Therefore, these systems consist of multiple layers of sub-horizontal galleries at different elevations, connected by deep vertical shafts, testifying stillstand and deepening phases of the karst base level, respectively. Cave patterns are strongly influenced by the structural settings of the host rocks; indeed, many passages follow bedding and/or fracture planes.

In this paper, we have investigated the Monte Conca gypsum karst system, which represents a multi-level system in exposed conditions (the term "level" refers to a specific phase of cave development sensu Palmer 1987, 2007; Ford \& Williams 1989). This complex has been studied by many scholars since the 1970s (Calvaruso et al. 1978; Madonia \& Panzica La Manna 1986; Panzica La Manna 1997; Biancone \& Vattano 2002; Cusimano et al. 2004; Vattano 2004, 2008). Due to its speleological features, it has been a Regional Natural Reserve since 1995. Between 2003 and 2008, we have carried out several explorations that allowed to increase the knowledge of the system. Using data resulting from these studies, we tried to build a morphoevolution model of the karst system, also in relation to the overall landscape geomorphological evolution.

\section{SETTING}

The gypsum karst system of Monte Conca developed in the homonymous relief (437 $\mathrm{m}$ a.s.l.), which is located in south-central Sicily in the Caltanissetta province, near the village of Campofranco.

The climate setting is of the Mediterranean type with a remarkable seasonality of precipitation. The average annual precipitation is $627.2 \mathrm{~mm}$, and about $80 \%$ of the rainfall is concentrated in the autumn-winter seasons, whereas only $5 \%$ occurs in the trimester June, July, August. The average annual temperature is $17.2^{\circ} \mathrm{C}$, but during the summer season the maximum temperature may exceed $45^{\circ} \mathrm{C}$.

In the study area, Messinian gypsum rocks of Serie Gessoso-Solfifera outcrop (Baldacci 1886; Decima \& Wezel 1971; Catalano 1986). The evaporites are made up of branching selenite, banded selenite, massive selenite and detritical gypsum, arranged in centimetric to metric beds separated by thin marl and carbonate layers. Thick massive evaporitic carbonates are, in some places, intercalated between the gypsum beds. The gypsum unit 


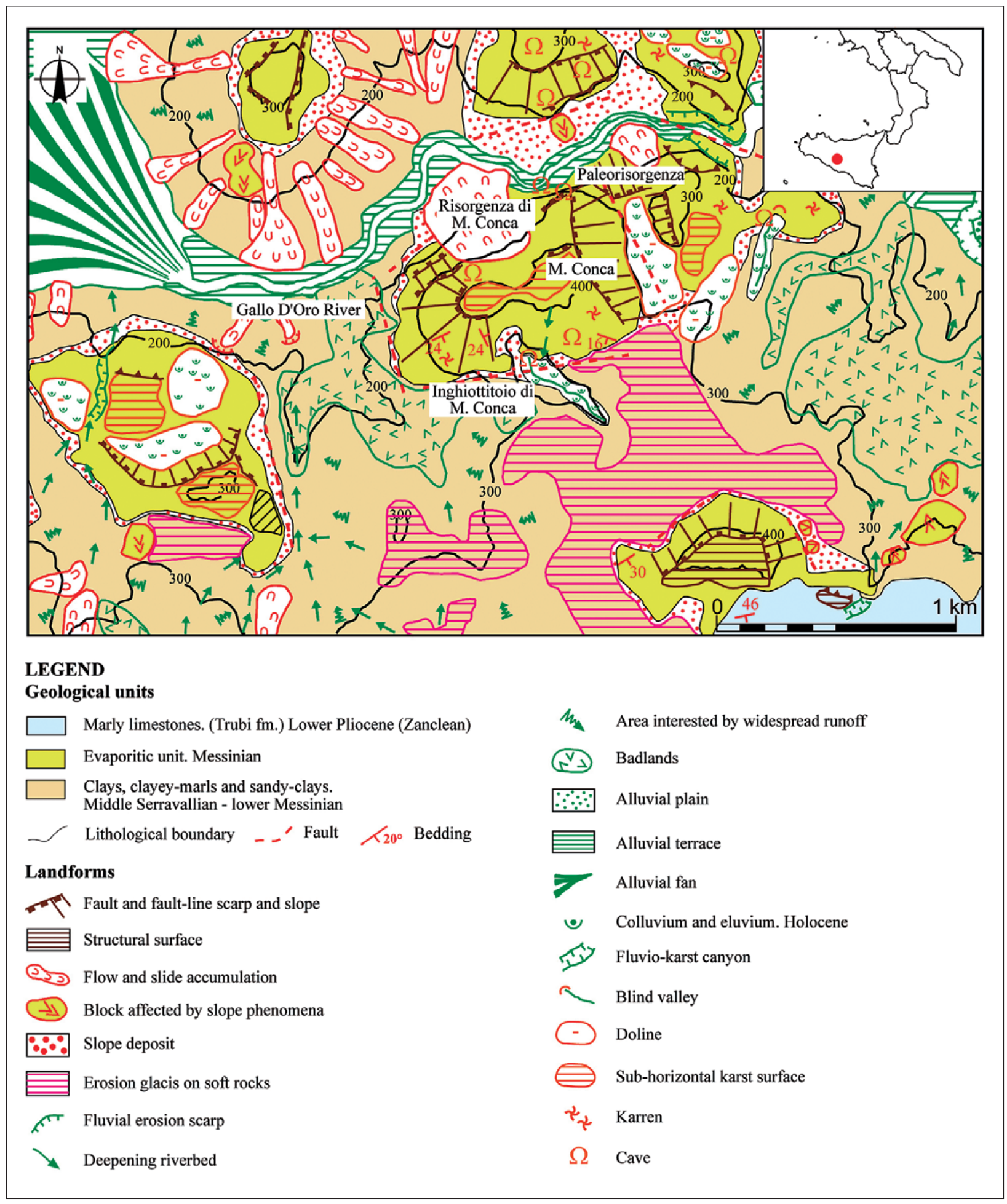

Fig. 1: Geomorphological sketch of Monte Conca area.

lies on clays, marly-clayey and sandy-clayey formations of the lower Messinian-middle Serravallian (equivalent to the Terravecchia and Castellana formations), and is overlain locally by marly limestones of the Trubi formation (Zanclean) (Fig. 1). 
These successions are affected by the Plio-Pleistocene tectonic phases that generated south-verging foldand-thrust belts, and E-W and to a lesser degree N-S and NW-SE high-angle faults that produced lateral contacts between the Messinian gypsum units and the older marly-clayey deposits.

The geomorphological setting is mainly marked by isolated reliefs in gypsum rocks and by topographic depressions cut in sandy-clayey and marly-clayey sequences (Fig. 1). The gypsum reliefs are connected with the clayey depressions by wide fault-line scarps, the analysis of which displays exceptional relief inversion phenomena.

Gypsum reliefs show surface karst landforms and well-developed caves. Surface karst landforms consist of several types of karren, dolines, and blind valleys, cut in non-karstifiable rocks and ending against gypsum thresholds. The caves are characterized by different stories of superimposed sub-horizontal galleries connected by deep shafts.
The geomorphological survey also showed landforms due to fluviokarst, hillslope, fluvial processes, structural landforms, and sub-horizontal surfaces due to "planation" processes. In particular, relict erosion surfaces cut on gypsum rocks linked to marginal solution, as well as erosion glacis on soft rocks located along the marly-clayey slopes, have been found. Erosion glacis on soft rocks and "planation" surfaces develop downward in an arranged succession between $600 \mathrm{~m}$ and $140 \mathrm{~m}$ a.s.l., and they are formed during stillstand phases of the erosion base level.

The area is also characterized by landforms due to lowering of the erosion base level, such as fluviokarst canyons, $\mathrm{V}$-shaped valleys and great fluvial scarps. Landforms linked to growing relief energy, such as selective erosion scarps bordering the gypsum reliefs, and landforms due to deep-seated gravitational slope deformation phenomena, favored by the presence of brittle formations (i.e., gypsum) overlying ductile units (i.e., clays/marls), are also present (Fig. 1).

\section{THE KARST SYSTEM}

The Monte Conca karst system represents the longest and deepest gypsum karst system in Sicily, reaching about 2.4 $\mathrm{km}$ in length and $130 \mathrm{~m}$ in depth. It consists of a sink cave (Inghiottitoio di Monte Conca), a resurgence (Risorgenza di Monte Conca) and a relict resurgence (Paleorisorgenza) (Fig. 2). At large scale, it is characterized by different superimposed levels of sub-horizontal galleries connected by vertical shafts, which are developed in adjustment to the contemporary geomorphological setting.

\section{THE INGHIOTTITOIO DI MONTE CONCA}

The Inghiottitoio di Monte Conca is located at the base of the south-western slope of the homonymous gypsum relief, at the end of an allogenic blind valley incised on the lower Messinian-middle Serravallian marly-clayey formations. The cave is entirely developed in selenite gypsum arranged in centimetric to metric sub-horizontal beds, with thin marl and carbonate intercalations. The cave pattern is influenced by fractures (joints and faults), mainly N-S, NW-SE and secondary NE-SW and $\mathrm{E}-\mathrm{W}$ oriented, while the shape of the passages is linked to solution and erosion processes under vadose conditions (Figs. 3 and 4).

Until 2003, the Inghiottitoio di Monte Conca was known to have been formed by a swallow hole into which the surface stream sinks underground, an upper horizontal gallery, a sequence of four shafts and a lower gallery ending in a sump, for a total surveyed length of about $500 \mathrm{~m}$ and a vertical range of about $-108 \mathrm{~m}$ (Calvaruso et al. 1978; Madonia \& Panzica La Manna 1986).

The upper gallery, about $100 \mathrm{~m}$ long, is developed along N-S and NW-SE oriented fractures; the walls are characterized by solution notches, linked to persistent water levels at different elevations, and by shelves due to differential solution of gypsum beds.

After this gallery, a sequence of four waterfall shafts offset by short horizontal passages occurs; the shafts, 11, 12,35 and $26 \mathrm{~m}$ deep, respectively, are formed by vadose water flowing downward along N-S, NE-SW and NW-SE oriented fractures (Fig. 5). Common features of all shafts are rounded cross sections, carbonatic flowstone along the walls where water flows and small ponds at the bottom of each pit.

The lower gallery, about $450 \mathrm{~m}$ long, is developed from the base of the last shaft; its pattern is alternately straight and meandering, according to the fracture systems, and its height ranges from $70 \mathrm{~cm}$ to $7-8 \mathrm{~m}$. This passage is characterized by ceiling half-tubes linked to dissolution of water during sediment-filling phases (cfr. Pasini 2009), ceiling cupolas due to flooding episodes, and by solution notches and small shelves along the walls. The inner part of the lowest gallery contains a perennial stream fed by a sinking stream, groundwater and a small sulfur spring. 


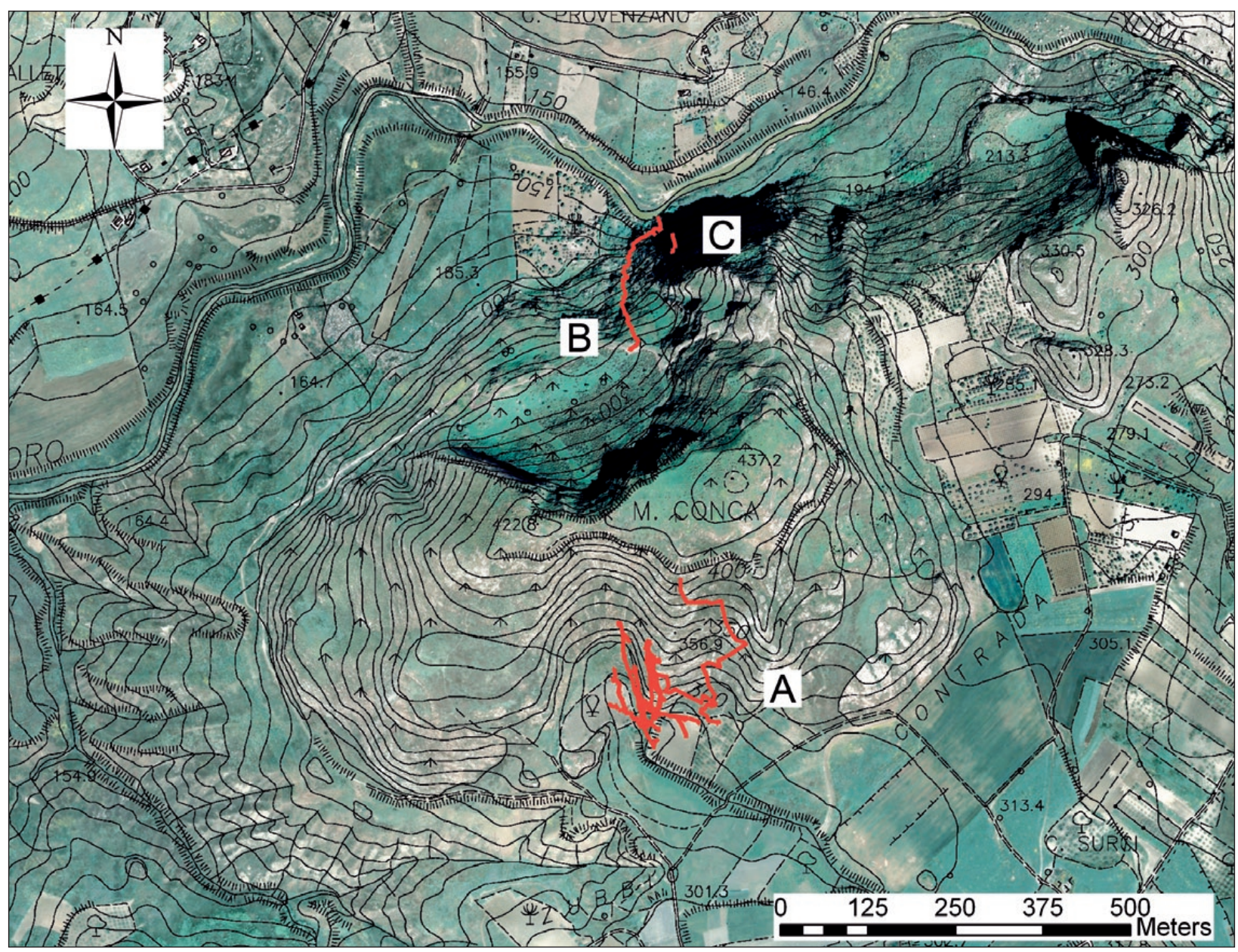

Fig. 2: Panoramic view of the Monte Conca gypsum karst system. In red survey lines of: A. Inghiottitoio di Monte Conca; B. Risorgenza di Monte Conca; C. Paleorisorgenza (Orthophoto and topographic map from Sicilian Regional Environmental Department).

Explorations carried out between 2003 and 2008 have discovered about $1.5 \mathrm{~km}$ of relict vadose passages at intermediate elevations between the upper and the lower gallery, most of which are correlatable with the level of the inactive resurgence (Vattano 2004, 2008). These branches include sub-horizontal galleries (New branches, Yawns and Polygons galleries), meandering passages gently dipping to the elevation of the lower gallery (Meander, Glass Pieces Gallery), and about $24 \mathrm{~m}$ high shafts where only dripping phenomena occur (Conulites and Stefano shafts). These galleries are generally narrow, straight and developed along the NNW-SSE and secondary W-E and NE-SW directions; their cross sections are influenced by sub-horizontal bedding planes, by steeply inclined fractures or by antigravitative evolution (cfr. Pasini 2009) (Fig. 6). Most of these passages end to the south of the present swallow hole (Fig. 3, points a, b and c); these conduits have an upward trend to the south and become too narrow to follow due to filling sediment and/or collapsed materials, which leads to their entire obstruction.
Some passages instead seem to be developed to the north (Fig. 3, points $d$ and $f$ ) at the same elevation as the gallery of the Paleorisorgenza. These conduits are very narrow with muddy floors and terminate in collapse chambers of different sizes.

\section{THE RISORGENZA DI MONTE CONCA}

The Risorgenza di Monte Conca is the active resurgence of the karst system (Fig. 7 A). It is located at the base of the north slope of the Monte Conca relief near the elevation of the Gallo D'Oro River, which represents the local base level of the entire karst system. The cave is developed in thick beds of centimetric to decimetric selenite gypsum crystals, and its pattern is influenced by NE-SW and NW-SE fracture systems.

The cavity, $260 \mathrm{~m}$ long, consists of two superimposed sub-horizontal galleries and reaches a positive vertical range of about $10 \mathrm{~m}$.

The lower gallery is connected to the upper one through a $5 \mathrm{~m}$ deep shaft located in the inner sector of 


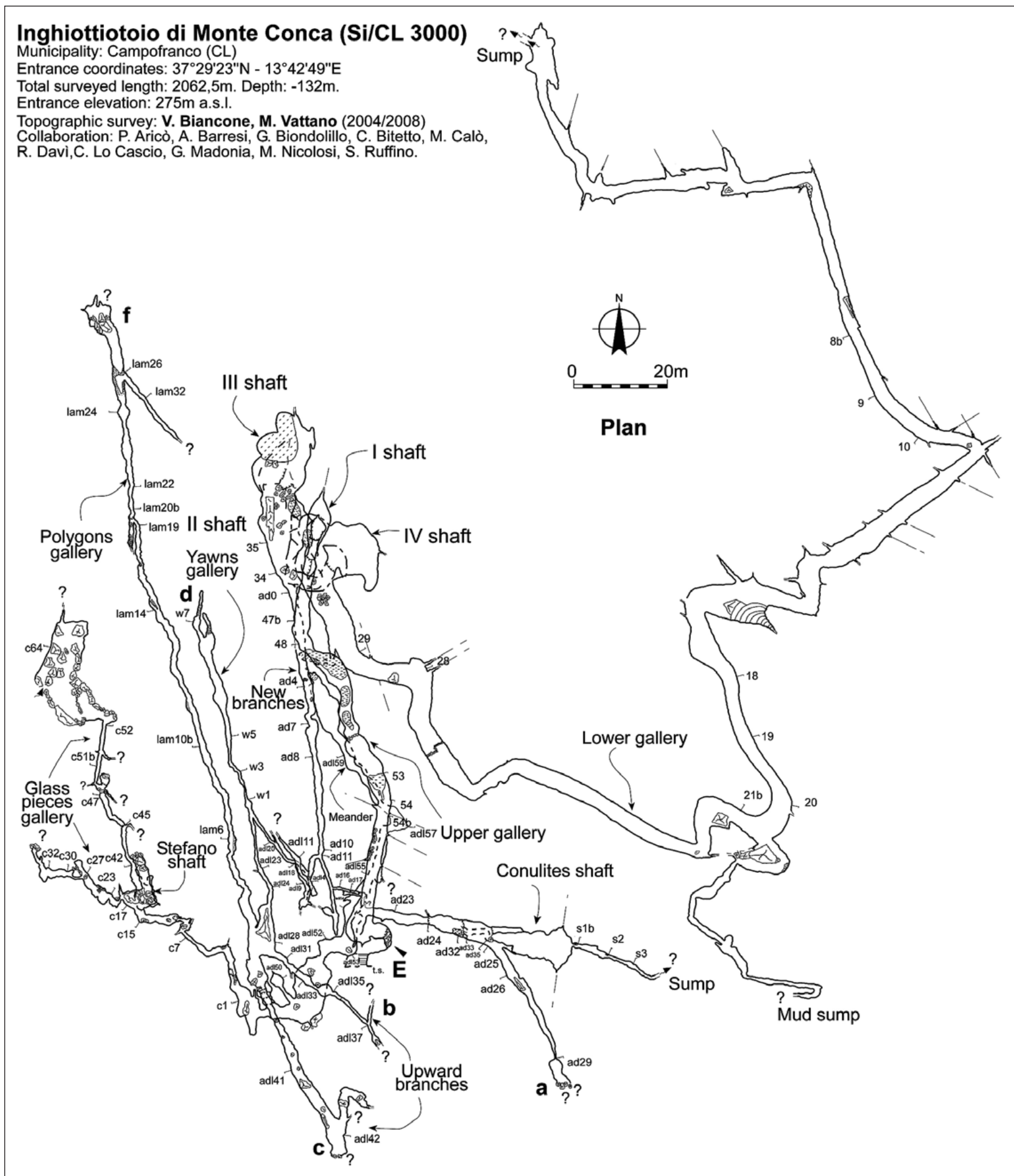

Fig. 3: Plan view of the Inghiottitoio di Monte Conca (modified from Vattano 2008).

the cave. The gallery is practicable only for a few meters, most of this being completely water-filled also in the dry season. The water level lies at the same elevation as the spring along the Gallo D'Oro River and is in equilibrium with the present local base level.
The upper gallery is developed along the NNE-SSW direction, although the conduit pattern is influenced by NE-SW and NW-SE fracture systems. The gallery shows nearly circular and eight-shaped cross sections with heights between 1 and $6 \mathrm{~m}$ and widths ranging from 70 


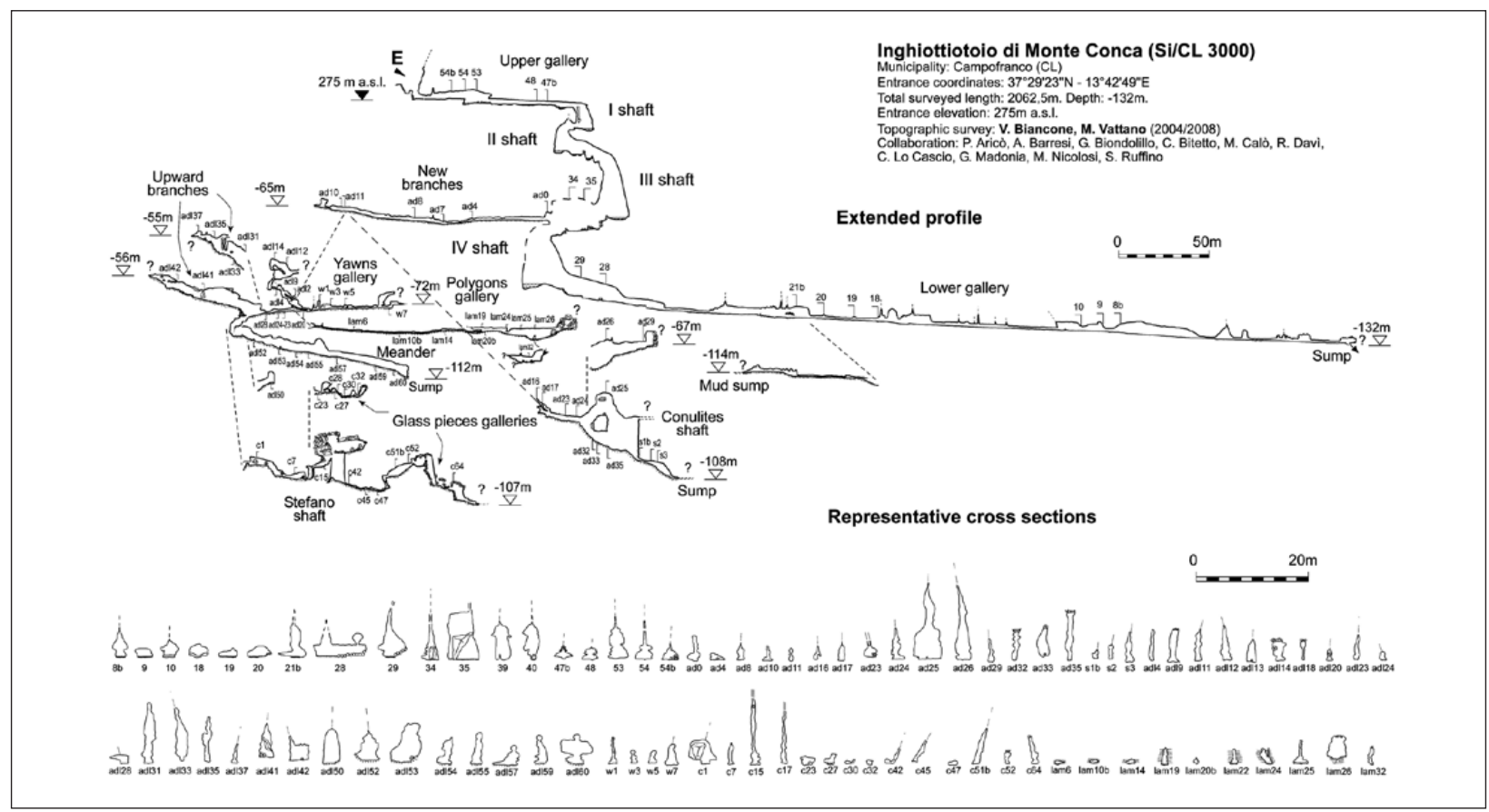

Fig. 4: Inghiottitoio di Monte Conca, cave map with extended profile and cross sections (modified from Vattano 2008).

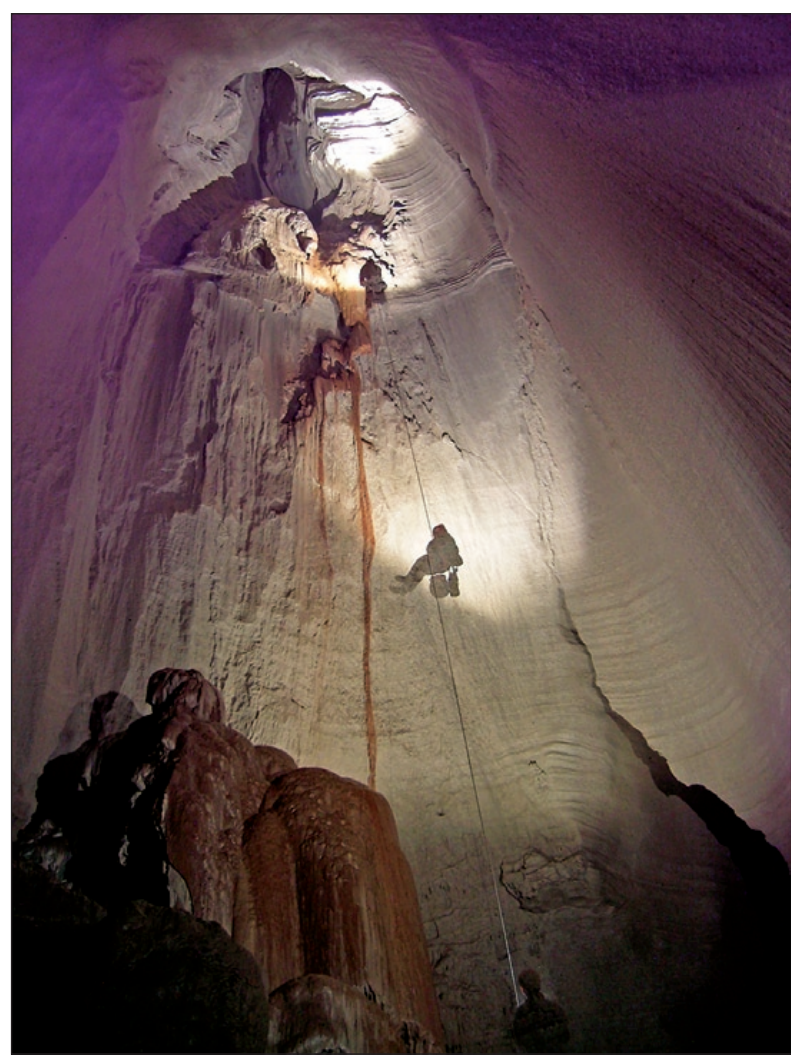

Fig. 5: The $4^{\text {th }}$ shaft of the Inghiottitoio di Monte Conca. This is a $26 \mathrm{~m}$ deep waterfall shaft developed at the junction of $\mathrm{N}-\mathrm{S}$ and $N W$-SE fracture systems. Carbonate flowstones cover breakdown blocks at the bottom and the wall where water flows (Photo: $M$. Vattano).

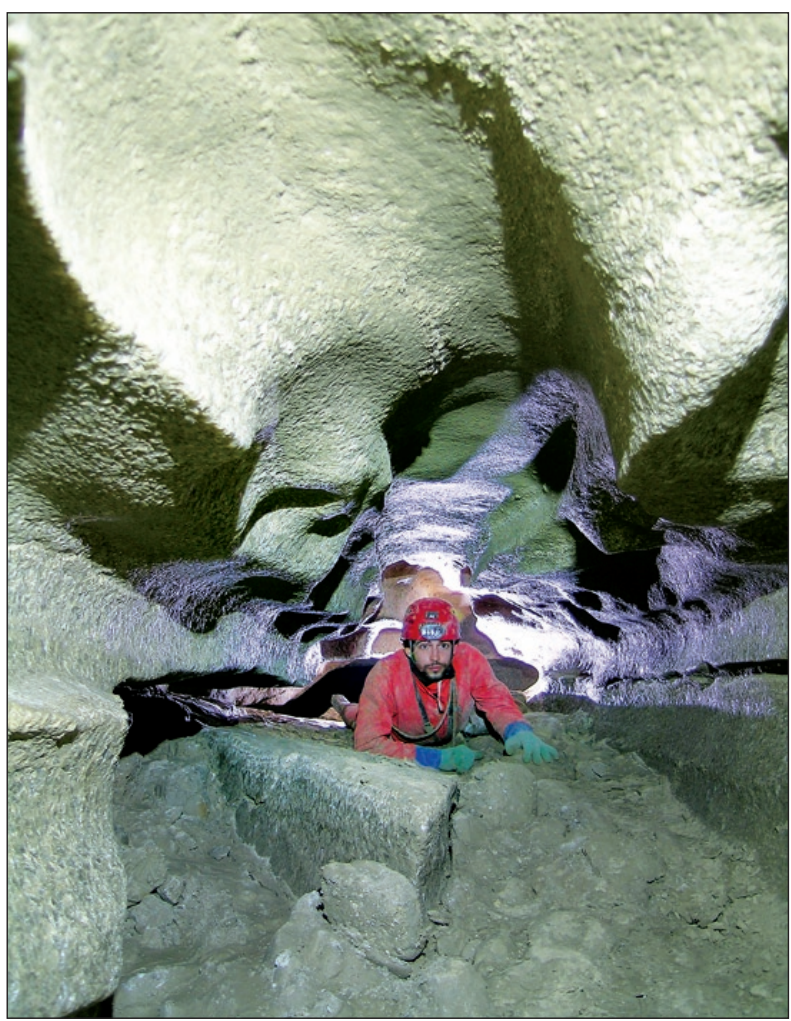

Fig. 6: Inghiottitoio di Monte Conca, sub-horizontal inactive gallery (Polygons Gallery) with morphologies influenced by alluvial sediment fill. A well developed ceiling half-tube on the roof and several solution notches in the walls are present. The different altitudes of solution notches are linked to lowering of the piezometric surface. The floor is covered by dried alluvial sediments (Photo: M. Vattano). 
Risorgenza di Monte Conca (Si/CL 3001)

Municipality: Campofranco (CL)

Entrance coordinates: $37^{\circ} 29^{\prime} 46^{\prime \prime} \mathrm{N}-13^{\circ} 42^{\prime} 49^{\prime \prime} \mathrm{E}$

Total surveyed length: $260,5 \mathrm{~m}$. Vertical range: $+10 \mathrm{~m}$.

Entrance elevation: $145 \mathrm{~m}$ a.s.I.

Topographic survey: V. Biancone, M. Vattano (2003)

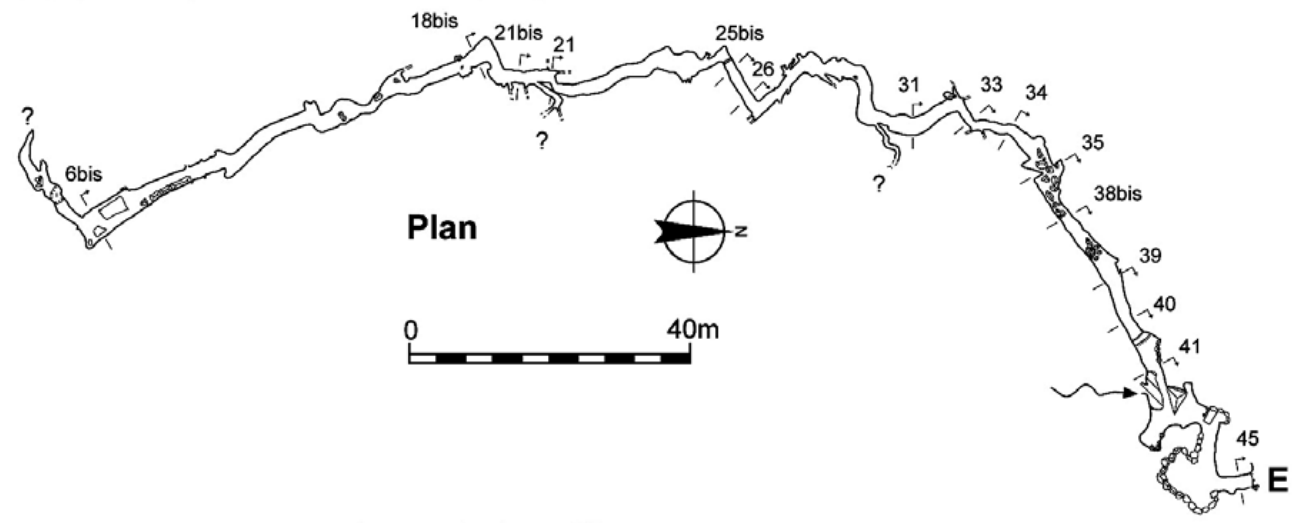

\section{Extended profile}
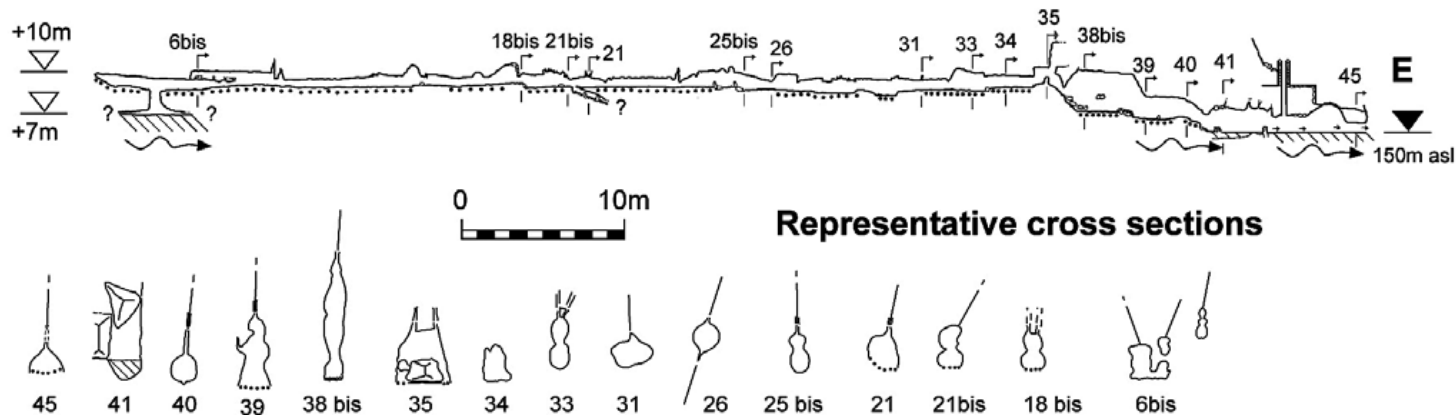

Representative cross sections<smiles>CC(C)OC1CCC1</smiles>

25 bis

2121 bis 18 bis 6 bis

Paleorisorgenza di Monte Conca

Municipality: Campofranco (CL)

Entrance coordinates: $37^{\circ} 29^{\prime} 46^{\prime \prime} \mathrm{N}-13^{\circ} 42^{\prime} 51^{\prime \prime} \mathrm{E}$

Total surveyed length: $42 \mathrm{~m}$

Entrance elevation: $190 \mathrm{~m}$ a.s. I.

Survey and Drawn: M. Vattano (2009)

Collaboration: G. Ceresia, M. D'Agostino, R. D'Aleo, R. Davì, S. Inzerillo, P. Valenti
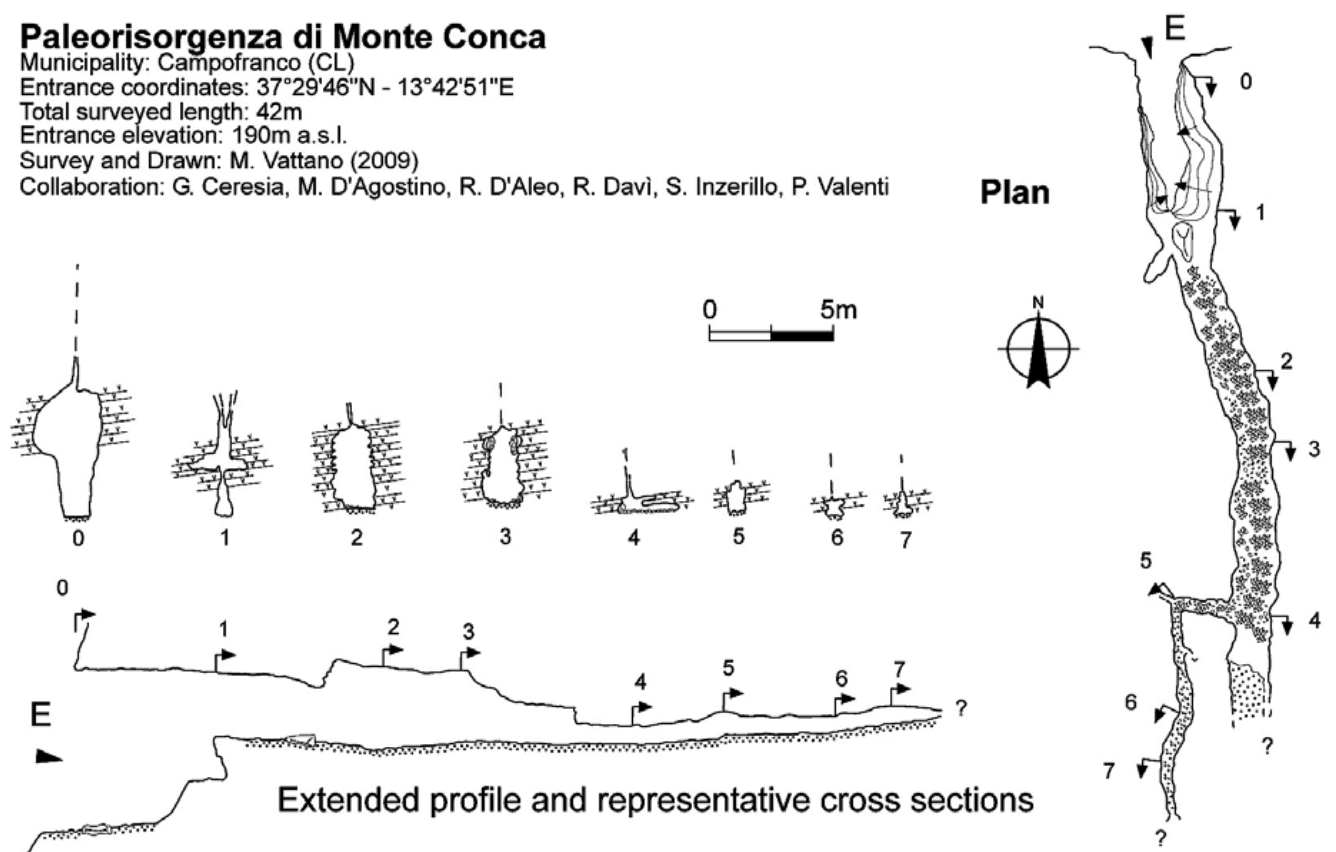

B

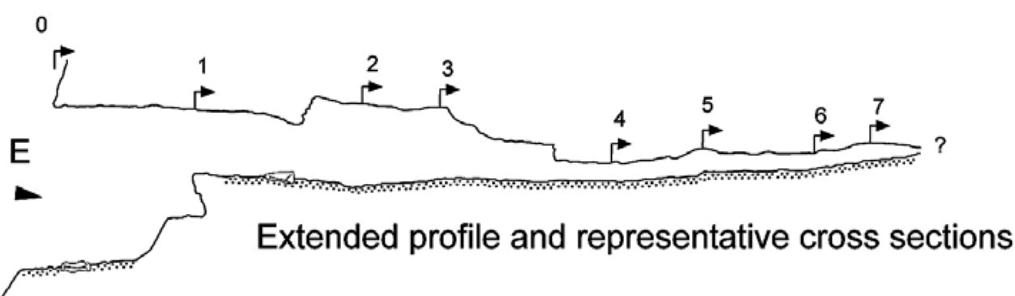

Fig. 7: Cave map of: A) Risorgenza di Monte Conca; B) Paleorisorgenza (modified from Vattano 2008). 
$\mathrm{cm}$ to $2 \mathrm{~m}$. These particular cross sections are linked to flooding phases, indeed this gallery may be flooded during heavy rainfall.

\section{THE PALEORISORGENZA OF MONTE CONCA}

The Paleorisorgenza is located in the northern scarp of the Monte Conca relief, about $40 \mathrm{~m}$ above the actual resurgence and slightly displaced laterally. The cave consists of an inactive sub-horizontal gallery that is elongated in the N-S direction (Fig. 7 B) along the main discontinuity planes (Vattano 2004, 2008). In the inner part of the cave, a narrow tributary, E-W and N-S oriented, is developed for some meters decreasing in size up to its blockage by alluvial sediment filling.

The main gallery, about $30 \mathrm{~m}$ long, terminates abruptly in a choke formed by clayey alluvial sediments. The sector near the entrance is characterized by the presence of several levels of shelves due to selective dissolution processes, while in the central sector the walls are masked by alluvial deposits, made up mainly of sands and imbricated pebbles whose analysis suggests a S-N paleoflow direction (Vattano 2010).

\section{EVOLUTION OF THE KARST SYSTEM}

The general setting of the Monte Conca karst system reflects the features of a classic gypsum karst system under unconfined conditions; it is composed of a main drainage tube, characterized by rapid flowing water, with usually inactive secondary tributaries locally filled by alluvial or breakdown deposits (Forti \& Sauro 1996; Forti \& Rossi 2003)

To better understand the geomorphological evolution of the karst system, surface geomorphological data of the area were considered.

Analysis of sub-horizontal surfaces (relict karst surfaces, erosion glacis on soft rocks, rock-cut terraces and sub-horizontal underground galleries) located at different elevations, relict landforms (hanging valleys), deepseated gravitational slope deformations and landforms due to downcutting processes (fluvial-karst canyons and underground shafts) allowed for the recognition of a geomorphological evolution of the area influenced by an alternation of stillstand and lowering phases of the local erosion base level.

The lowering of the local erosion base level might be linked to a general uplift trend that might involve the gradual emersion of this area with the beginning of the geomorphological evolution, in agreement with geological data, since the early Middle Pleistocene (Vattano 2008).

The Monte Conca karst system recorded in detail stillstand and lowering phases of the local erosion base level with the development of sub-horizontal galleries and vertical shafts; the underground system recorded some stillstand phases whose surface evidences have been completely erased by erosive phenomena linked to fluvial downcutting phases and slope processes.

Until 2003, when the Inghiottitoio di Monte Conca was known to have been formed by two subhorizontal galleries located at different elevations con- nected by a sequence of four shafts, the origin of the system was considered rather simple. It was a linear karst system that directly connected sink point to resurgence point, where stillstand phases (testified by sub-horizontal galleries) followed by more or less sudden lowering phases of the erosion base level (testified by wall notches at different elevations, small entrenchments in the floor of the gallery, pits and relict galleries) were recognized.

After the recent explorations carried out in the Inghiottitoio di Monte Conca, understanding the evolution of this karst system has become more complex. These explorations led to the discovery of: a) relict narrow subhorizontal branches lying at an intermediate elevation between the upper and lower galleries, which are correlatable to the relict resurgence; b) relict low-gradient passages that can be connected to the lower active gallery; c) inactive shafts connecting the gallery levels indicated in a) and b); d) different relict sink points, sealed by alluvial and/or breakdown deposits, which are located to the south and in a lower elevation than the active swallow hole and which are covered by thick debris and alluvial deposits from the surface slopes (Figs. 3 and 4).

The presence of sub-horizontal galleries located at different elevations and connected by vertical shafts might be linked to successive stillstand and lowering phases of the local erosion base level that involves the progressive fall of the piezometric level and the consequent inactivation of the upper galleries. Nevertheless, in the Monte Conca karst system, the upper gallery is still active, receiving water from a sinking stream, while the galleries located at intermediate elevations and some passages connected to the lower gallery are inactive even during exceptional flood events.

The multi-story setting could be due to a structural control as in the gypsum karst caves of Sorbas in Spain, 
where the alternation of gypsum and pelitic beds plays an important role in the speleogenetic evolution of the karst (Calaforra 1998; Calaforra \& Pulido Bosch 2000, 2003). Despite the fact that marly interlayers are present in the gypsum successions of Sicily, they do not reach thicknesses and lateral continuity necessary to enable the development of semi-confined aquifers under phreatic conditions. Furthermore, in the Monte Conca system, subterranean forms such as proto-conduits in the ceiling and passages with triangular cross-sections, typical of the Sorbas systems, are completely absent.

The speleogenetic evolution of the Monte Conca gypsum karst system can be explained by several steps always linked to successive stillstand and lowering phases of the local erosion base level, but with the interference of surface geomorphological processes that affected the underground system complicating its normal speleogenetic evolution (Fig. 8).

During a first step, a system composed of the intermediate galleries that established to the piezometric level, developed. These conduits connected the sink points, located to the south and in a lower elevation than the actual active swallow hole, to the Paleorisorgenza.

This first stage was followed by a sudden lowering of the erosion base level that caused a negative vertical shift of about $40 \mathrm{~m}$ of the spring, the subsequent fall of the piezometric surface to a level close to that at present, and the inactivation of the Paleorisorgenza. The $4^{\text {th }}$ shaft, the Conulite and Stefano shafts began to develop, while the lower passage of the Inghiottitoio di Monte Conca and the passages of the Risorgenza were established along the new piezometric level. In the Inghiottitoio di Monte Conca low-gradient conduits (e.g., Meander, Glass Pieces Galleries) connected the intermediate passages to the lower gallery level.

On the surface landscape, the lowering of the erosion base level favored the increase of erosion processes (e.g., hillslope and fluvial processes), which allowed accumulation of thick hillslope and alluvial deposits at the base of the south slope of the Monte Conca relief; these deposits completely buried the sink points that fed the system and, consequently, the intermediate level of galleries became inactive.

The presence of thick deposits also modified the last sector of the blind valley, which recharged the karst sys-

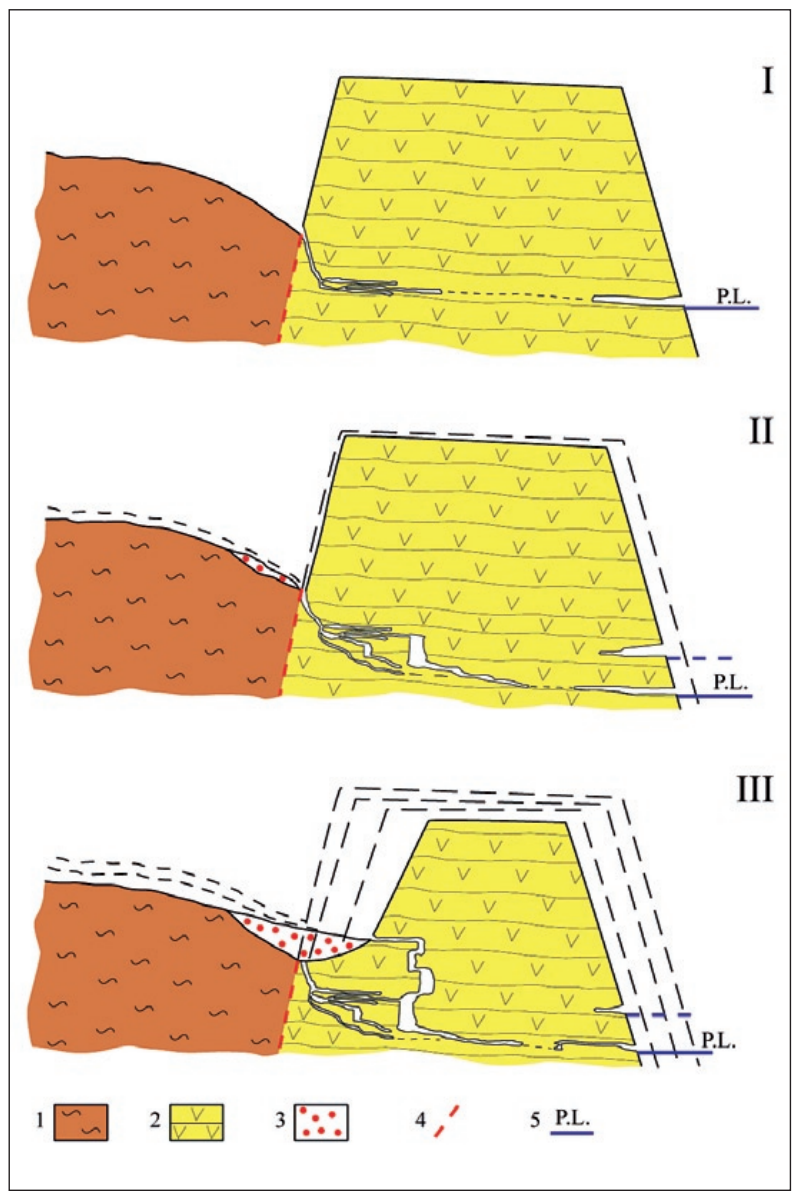

Fig. 8: Morphoevolution model of the Monte Conca gypsum karst system. 1: Marly-clay; 2: Gypsum; 3: Hillslope and alluvial deposits; 4: Fault; 5: Piezometric level. I: Genesis of the intermediate level of galleries linked to the Paleorisorgenza. II: Lowering of the karst base level-genesis of the lower gallery (connected to the Risorgenza di Monte Conca) and the $4^{\text {th }}$, Conulites and Stefano shafts. III: Hillslope processes, accumulation of hillslope deposits, and sealing of sink points that fed the intermediate galleries; genesis of the actual sink point and the $1^{\text {st }}, 2^{\text {nd }}$ and $3^{\text {rd }}$ shafts.

tem, causing a positive vertical shift of the swallow hole; a new sub-horizontal gallery, fed by a sinking stream, developed at a higher elevation. This gallery was rapidly connected with the active lower gallery through three vertical shafts $\left(1^{\text {st }}, 2^{\text {nd }}\right.$ and $3^{\text {rd }}$ shafts), which are located in the same weakness zone where the $4^{\text {th }}$ shaft has developed.

\section{CONCLUSIONS}

The Monte Conca karst system represents the longest and deepest gypsum karst system in Sicily, reaching about
$2.4 \mathrm{~km}$ in length and about $130 \mathrm{~m}$ in depth. 
The system reflects the typical gypsum caves under unconfined conditions, being composed of a main passage that develops between input and output points with usually inactive secondary tributaries.

In particular, the system is characterized by a multistory setting consisting of different tiers of low-gradient galleries sitting at different elevations and connected through vertical shafts.

The setting has been reached by a succession of stillstand and lowering phases of the karst base level, ac- cording to a regional uplifting trend, and by surface hillslope and fluvial processes, which have complicated the structure and the evolution of the whole karst system.

Topographical and geomorphological surveys carried out in the gypsum karst system and in the surrounding area show how the gypsum caves are very important archives for reconstructing the geomorphological evolution of an area adapting rapidly with the contemporary geomorphic setting and for easily recording the fluctuations of the karst base level.

\section{ACKNOWLEDGEMENTS}

We are grateful to our speleologist friends for their field assistance. We would like to acknowledge José Maria Ca- laforra, Jo De Waele and Paolo Forti for their helpful reviews during the preparation of this paper.

\section{REFERENCES}

Agnesi, V., Macaluso, T., Madonia, G. \& M. Panzica La Manna, 2003: Sicilia (Sicily).- Memoria Istituto Italiano di Speleologia, 14, 253-278.

Baldacci, L., 1886: Descrizione geologica dell'Isola di Sicilia (Geological description of Sicily Island).Memorie descrittive della Carta Geologica d'Italia, pp. 403, Roma.

Biancone, V. \& M. Vattano, 2002: Esplorazioni speleologiche nella Riserva Naturale Integrale "Monte Conca" (Campofranco-CL) (Speleological explorations in the "Monte Conca" Natural Protect area).Speleologia Iblea, 10, 205-211.

Calaforra, J.M., 1998: Karstologia de yesos (Gypsum karst).- Sci. Technol. Ser., 3, University of Almeria, pp. 384, Almeria.

Calaforra, J.M. \& A. Pulido-Bosch, 2000: Cave development in vadose settings in a multilayer aquifer, the Sorbas Karst, Almeria, Spain.- In: Klimchouk, A.B. et al. (eds.), Speleogenesis, Evolution of Karst Aquifers. National Speleological Society, pp. 382- 386, Huntsville.

Calaforra, J. M. \& A. Pulido Bosch, 2003: Evolution of the gypsum karst of Sorbas (SE Spain).- Geomorphology, 50, 173-180.
Calvaruso, E., Cusimano, G., Favara, R., Mascari, A. \& M. Panzica La Manna, 1978: Primo contributo alla conoscenza del fenomeno carsico nei gessi in Sicilia, Inghiottitotio di M. Conca (Campofranco - CL) (First contribution on the knowledge of gypsum karst in Sicily, Inghitottitoio di Monte Conca cave).- In: GS CAI Perugia, Proceeding of the $13^{\text {th }}$ Speleological National Conference, $30^{\text {th }}$ September $-4^{\text {th }}$ October 1978, Perugia, 1-4, Perugia.

Catalano, R., 1986: Le evaporiti messiniane. Loro ruolo nell'evoluzione geologica della Sicilia (Messinian evaporites. Their role in the geological evolution of Sicily).- Le Grotte d'Italia, 13, 4, 109-122.

Cusimano, G., Gatto, L., Hauser, S. \& L. La Pica, 2004: Idrogeologia ed idrogeochimica dell'area della riserva di Monte Conca (Caltanissetta) (Hydrogeology and Hydrogeochemistry of the Monte Conca Natural Protect area).- Naturalista Siciliano, 28, 4, 3-4, 1105-1124.

Decima, A. \& F. Wezel, 1971: Osservazioni sulle evaporiti siciliane della Sicilia centro meridionale (Observations on the Sicilian evaporites of Central-Southern Sicily).- Rivista Mineraria Siciliana, 22, 172-187.

Ferrarese, F., Macaluso, T., Madonia, G., Palmeri A. \& U. Sauro, 2002: Solution and re-crystallization processes and associated landforms in gypsum outcrops of Sicily.- Geomorphology, 49, 25-43. 
Ford, D.C. \& P.W. Williams, 1989: Karst Geomorphology and Hydrology.- Unwin Hyman, pp. 601, London.

Forti, P. \& U. Sauro, 1996: The Gypsum karst of Italy.- International Journal of Speleology, 25, 3-4, 239-250.

Forti, P. \& A. Rossi, 2003: Il Carsismo ipogeo nei gessi italiani (Gypsum speleogenesis in Italy).- Memorie Istituto Italiano di Speleologia, 14, 65-87.

Klimchouk, A.B. \& D.C. Ford, 2000: Types of karst and evolution of hydrogeologic settings.- In: Klimchouk, A.B. et al. (eds.), Speleogenesis, Evolution of Karst Aquifers. National Speleological Society, pp. 45-53, Huntsville.

Macaluso, T. \& U. Sauro, 1996a: The Karren in evaporite rocks: a proposal of classification.- In: Fornos, J.J. \& A. Gines, (eds.) Karren landforms. Universitat de les Illes Balears, pp. 277-293, Palma de Mallorca.

Macaluso, T. \& U. Sauro, 1996b: Weathering crust and Karren on exposed gypsum surfaces.- International Journal of Speleology, 25, 3-4, 115-126.

Macaluso, T. \& U. Sauro, 1998: Aspects of weathering and landforms evolution on gypsum slopes and ridges of Sicily.- Supplemento Geografia Fisica e Dinamica Quaternaria, 3, 4, 91-99.

Macaluso, T., Madonia, G., Palmeri, A. \& U. Sauro, 2001: Atlante dei Karren nelle evaporiti della Sicilia (Atlas of karren in the evaporites of Sicily).- Quaderni del Museo Geologico “G.G. Gemmellaro”, 5, 1-143.

Macaluso, T., Madonia, G. \& U. Sauro, 2003: Le forme di soluzione nei gessi (The solution forms in gypsum).- Memorie Istituto Italiano di Speleologia, 14, 55-64.

Madonia, P. \& M. Panzica La Manna, 1986: Fenomeni carsici ipogei nelle evaporiti della Sicilia (Speleogenesis in the evaporites of Sicily).- Le Grotte d'Italia, 13, 4, 163-189.
Palmer, A.N., 1987: Cave levels and their interpretation.National Speleological Society Bulletin, 49, 50-66.

Palmer, A.N., 2007: Cave Geology.- Cave books, pp. 454, Dayton.

Panzica La Manna, M., 1997: Aspetti del fenomeno carsico sotterraneo nel territorio di Milena (CL) (Aspects of speleogenesis in the Milena area).- In: La Rosa V. (ed.) Dalle Capanne alle Robbe. La storia lunga di Milocca - Milena. pp. 27-38, Milena.

Pasini, G., 2009: A terminological matter: paragenesis, antigravitative erosion or antigravitational erosion?.- International Journal of Speleology, 38, 2, 129-138.

Sauro, U., 1996: Geomorphological aspects of gypsum karst area with special emphasis on exposed karst.- International Journal of Speleology, 25, 3-4, 105-114.

Sauro, U., 2003: Aspetti evolutivi del paesaggio carsico nei gessi in Italia (Evolution of gypsum karst landscapes in Italy).- Memorie Istituto Italiano di Speleologia, 14, 41-45.

Vattano, M., 2004: Geomorphological aspects of Monte Conca Karst system (Caltanissetta, Sicily).- Memorie dell'Istituto Italiano di Speleologia, 16, 103-114.

Vattano, M., 2008: Geomorphological evolution of evaporite karst areas in South-Central Sicily by relationship analysis between hypogean karst landforms and surface landforms.- PhD thesis. Palermo University, pp. 250.

Vattano, M., (2010: The "Paleorisorgenza" of the Monte Conca karst system (south-central Sicily).- Speleologia Iblea, 14, 137-141. 